\title{
Bridging Ethnic Diversity through Service-Learning on Teaching Chinese Characters for Surabaya-Indonesia Toddler
}

\author{
Olivia $^{*}$
}

Chinese Literature Department, Faculty of Letters, Petra Christian University, Jl. Siwalankerto No.121-131, Surabaya 60236, East Java, Indonesia

\begin{abstract}
This social activity is to give low-income children a chance to let the, understand the evolution of Chinese characters, hope through this activity, can attract the group of children to have more interested in other language, especially Chinese language. To understand the Chinese culture, no longer discriminate against the Indonesian Chinese culture. Evidence of discrimination against Chinese Indonesians can be found throughout the history of Indonesia, although government policies implemented since 1998 have attempted to redress this. Due to this discrimination, Chinese Indonesians have suffered an identity crisis, unable to be accepted by both native Chinese and native Indonesians. With this program, there is a hope to bridge the differences that exist with the introduction of the Chinese character on poor children in Surabaya, to let them more understand about Chinese language and the culture behind. And create a better relationship for the next generation in Indonesia. After the progress, we asking the children about this program, and they said they love it and wish to know more about China and their culture.
\end{abstract}

Keyword: Chinese character, ethnic diversity, service-learning, Surabaya - Indonesia, toddler.

\section{The background}

Indonesia, the world's fourth-most-populous country, is a plural democracy that no longer recognizes racial divisions. For centuries, people from China have been active in the thousands of islands that make up Indonesia, often as traders working alongside indigenous farmers and kings. The Dutch colonial government imposed a system of racial divisions here-as they did in South Africa-before Indonesian independence in 1949, but many of the modern laws concerning the Chinese population were passed during the Cold War. In 1965, six Indonesian army generals were killed by other high-ranking officers, and conservative generals backed by the United States responded by accusing Communist Party leaders of attempting to orchestrate a coup. Over the months that followed, military and civilian groups killed an estimated 500000 to 1000000 people, exterminating the world's third-largest Communist Party (behind China and the Soviet Union) while torturing and killing untold numbers of people accused of association with communists. The government the military formed afterward, led by Suharto, ruled Indonesia until 1998. But 20 yr after the end of the violently anti-communist Suharto dictatorship, which banned Chinese-language materials and suspended relations with Beijing for decades, peoplein the region still face official discrimination, despite the intervention of the government's human rights commission. An ethnic Indonesian Chinese devotee burns joss-sticks at a temple in Surabaya, eastern Java island, on the eve of the Lunar New Year. Questions about the role of Chinese Indonesians have loomed large in the world's most populated Muslim-majority country over the past few months as Jakarta Governor Basuki Tjahaja Purnama, known simply as "Ahok," the most prominent politician of Chinese descent in decades, wages a re-election campaign while facing trial for allegedly insulting Islam [1].

Indonesia has suffered a tumultuous past in stages: under the oppression of local rulers, European colonists, Japanese invaders, corrupt military dictatorships, and currently multinational corporations. This history produced a permanent underclass of people, but also instilled strength of spirit and skill at survival in most ordinary Indonesians. In this new century, the future of Indonesia, as of much of the world, remains problematic and uncertain [2]. Indonesians now must struggle with their religious diversity and a minority of people prone to terrorism and violence (which includes Muslims, Christians, and animists), threatening the stability of their lives, communities, and nation [2]. Diversely modern Asian trends affect Indonesians: from heroes of Hong Kong martial arts action films; to songs, dances, and fashions of India's spectacular Bollywood movies; to head wraps worn by Indonesian youth following the contemporary dance style called joget. Joget moves to the lively Indian and Arabic inspired rhythms of dangdut, a Malay/Indonesian pop music craze. Through mass media and ever changing fashions in urban centers, more than ever before Indonesians enjoy access to stylistic trends from both hemispheres [2].

The author feels that the ethnic diversity problems in Indonesia have existed long ago, and started from misunderstandings between ethnic groups, as achild we used to look at other ethnic as "the others". Chinese ethnic not

*Corresponding author: olivia@petra.ac.id 
going to Indonesian state school, they going to public school, have an exclusive community. And the local people never get along with Indonesian-Chinese people, they had little chance to communicating and to do activities together. That's why author think to do this kind of service-learning in Surabaya. Surabaya is Indonesia's second largest city and the capital of East Java province. The name "Surabaya" is derived from the words Sura or Suro (shark) and Baya or Boyo (crocodile). As the second largest metropolitan city in Indonesia, Surabaya is growing rapidly but still can't avoid the problems of chaotic social environment. Due to rapid urban growth, but uneven and equilibrium, causes an unbalanced social environment, without improving the quality of life, especially for the growth and development of children from $0 \mathrm{yr}$ to $18 \mathrm{yr}$.

"The underlying issue is that our voices are not being heard. We need to have our voices heard." This was the clear message from the children of Surabaya and the motivation for World Vision's urban pilot project in Indonesia. The project is based in the village of Surabaya. Poor sanitation and environmental conditions, early marriage, violence and school drop outs were identified by children as some of the major issues affecting their community. However the primary concern expressed by the children was their lack of voice and participation in decisions that affect their lives. The development of the "Child Friendly Village" concept has been selected by the children as the vehicle for opening up opportunities to engage with decision-makers and promote child rights [3]. Such a disadvantaged social environment is potentially detrimental to the quality of life of child growth and development, particularly in the "backward" enclave areas in the heart of Surabaya.

The goals of higher education include more than high academic achievement. The mission statement of nearly every institution of higher education refers to educating its students "morally, and for good citizenship" [4]. Our university is a private university, and our students mostly are Chinese people. And service-learning is an activity that combined science in school and practice in society. Students in service-learning programs consisting of regular interaction with people from different ethnic backgrounds were more likely to report growth in self-knowledge and personal growth [5]. With this program, we hope to bridge the differences that exist with the introduction of the Chinese character on poor children in Surabaya, to let them more understand about Chinese language and the culture behind. The major study students also got a chance to practice their professional skill to make the learner have a systematic and standard basic train, to reach a win-win solution.

The problems faced by World Vision Indonesia as our partners are: how to present a social condition that is conducive to the development of the child, especially in relation to the strengthening of the institution of community activities that concerns the importance of children, the family environment and alternative care, education and the utilization of child free time, their right and child freedom.

\section{The literature review}

According to the Shuowen Jiezi, Chinese characters are developed on six basic principles. The first two principles produce simple characters, known as 文 wén [6]:

(i). 象形 xiàngxing: Pictographs, in which the characteris a graphical depiction of the object it denotes. Examples: 人 rén "person", 日 rì "sun", 木 mù "tree/wood".

(ii). 指事 zhǐshì: Indicatives, or ideographs, in which the character represents an abstract notion. Examples: 上 shàng "up", 下 xià "down", 三 sān "three".

The remaining four principles produce complex characters historically called 字 zi (although this term is now generally used to refer to all characters, whether simple or complex). Of these four, two construct characters from simpler parts:

(i). 會意/会意 huiyi: Logical aggregates, in which two or more parts are used for their meaning. This yields a composite meaning, which is then applied to the new character. Example: 東/东 $d \bar{n} n g$ "east", which represents a sun rising in the trees.

(ii).形聲/形声 xingshēng: Phonetic complexes, in which one part — often called the radical—indicates the general semantic category of the character (such as water-related or eye-related), and the other part is another character, used for its phonetic value. Example: 晴 qing "clear/fair (weather)", which is composed of 日 rì "sun", and 青 qīng "blue/green", which is used for its pronunciation.

The last two principles do not produce new written forms; instead, they transfer new meanings to existing forms:

(i). 轉注/转注 zhuănzhù: Transference, in which a character, oftenwith a simple, concrete meaning takes on an extended, more abstract meaning. Example:網/网 wăng "net", which was originally a pictograph depicting a fishing net. Over time, it has taken on an extended meaning, covering any kind of lattice; for instance, it can be used to refer to a computer network.

(ii). 假借 jiǎjiè: Borrowing, in which a character is used, either intentionally or accidentally, for some entirely different purpose. Example: 哥 $g \bar{e}$ "older brother", which is written with a character originally meaning "song/sing", now written 歌 gēe. Once, there was no character for "older brother", so an otherwise unrelated character with the right pronunciation was borrowed for that meaning.

Chinese characters are written to fit into a square, even when composed of two simpler forms written side-by-side or top-to-bottom. In such cases, each form is compressed to fit the entire character into a square. 


\subsection{Stages of Chinese writing [7]}

Given its immense time depth, the Chinese writing system is far from static. After the early evolution during the Shang dynasty, the script continued to evolved. Visually it became increasingly more linear, more stylized and less resembling of the natural objects. It also grew in complexity, as the innovations of semantic determinatives (radicals) and phonetic complements continued to be applied to form new words. Scholars have conveniently divided different styles of Chinese writing into a number of "scripts". The following chart compares different Chinese characters in various forms throughout time.

$\begin{array}{cccccccc}\text { oracle } & \text { greater } & \text { lesser } & \text { clerkly } & \text { standard } & \text { running } & \text { cursive } & \text { modern } \\ \text { bone } & \text { seal } & \text { seal } & \text { script } & \text { script } & \text { script } & \text { script } & \text { simplified } \\ \text { jlaguwen } & \text { dazhuan } & \text { xiaozhuan } & \text { lishu } & \text { kaishu } & \text { xingshu } & \text { caoshu } & \text { flantizi }\end{array}$

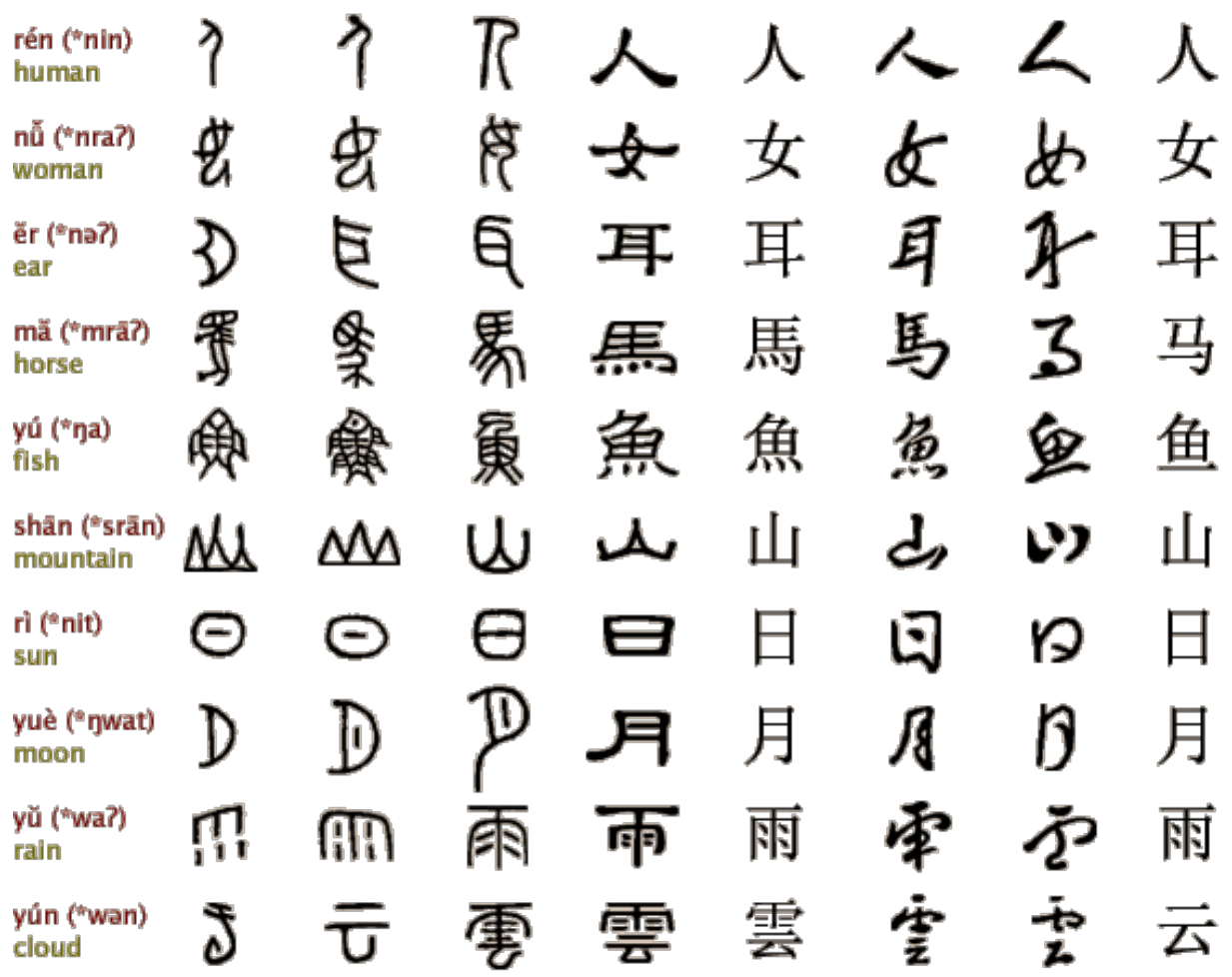

Fig. 1. Different Chinese characters in various forms throughout time. The pronunciation is that of Mandarin and of Old Chinese (1000-700 BCE).

The first four phases of Chinese writing trace the first 1,500-year history of Chinese and essentially encompass the evolution from a nascent pictographic and ambiguous writing script to a standardized system containing thousands of characters still in use today.

\section{Methodology}

To let the student prepare to teaching and have enough knowledge for sharing with the children, our Service Learning Project was started with literature review of the origin and development of Simplified Chinese.

Preparation by the lecturer are:

(i). Discuss with Mr. Rudy and team from Wahana Visi on 11 February 2015 at 10.00 at Wahana Vision Margorejo office.

(ii). After discussing with them, then discuss with students to follow up this service learning plan, it turns out the students also enthusiastically hear the opportunity to go directly to the field and apply the knowledge gained.

(iii). The briefing from Wahana Visi directly to students (Figure 1 and Figure 2) of Chinese Literature who attend Hanzi Character Study class done two weeks before midterm exams, because the teaching plan is done after final exams. And the students discussed the agreed time and location of teaching (Figure 3 ). 
(iv). The second briefing before midterm exam and the first three weeks' briefing after final exams from me as a lecturer on the materials and topics that will be given to the target community to be communicating with the children.

(v). A book written by Cecilia Lindqvist [8] is used as a reference material for students when teaching the children. Cecilia Lindqvist (Chinese name: Lin Xili 林西莉 (Lin Xili)) (born 4 June 1932) is a Swedish Sinologist. She is a professor and author of several books on China.

Our student preparation:

(i). perform service learning activities to introduce a Simplified Chinese character in Children Study Group.

(ii). Create a module and props to facilitate children recognize letters characters.

(iii). Make stories and games to attract children's interest in knowing the language.

(iv). Observing the surrounding and finding the problem dealing when interaction with the children.

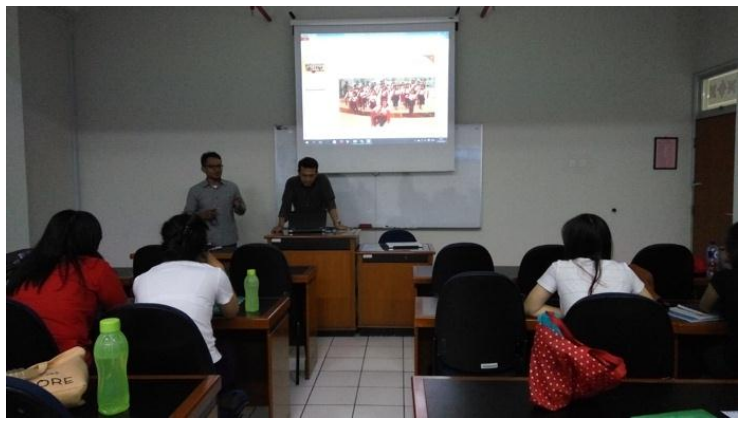

Fig. 2. Introduction about Wahana Visi (World Vision-Indonesia).

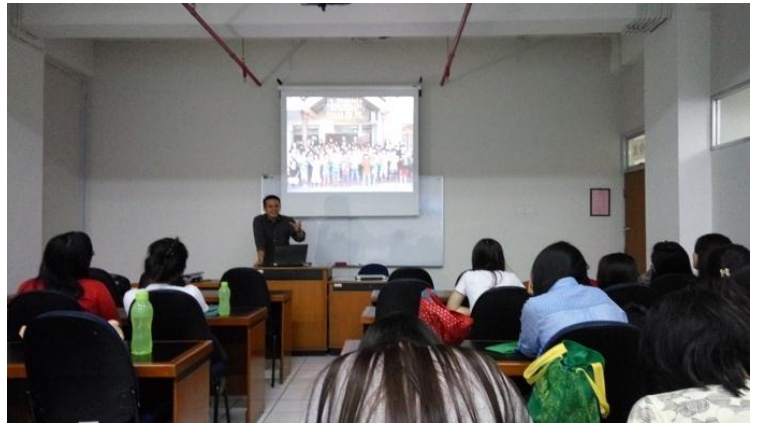

Fig. 3. Briefing from Wahana Visi.

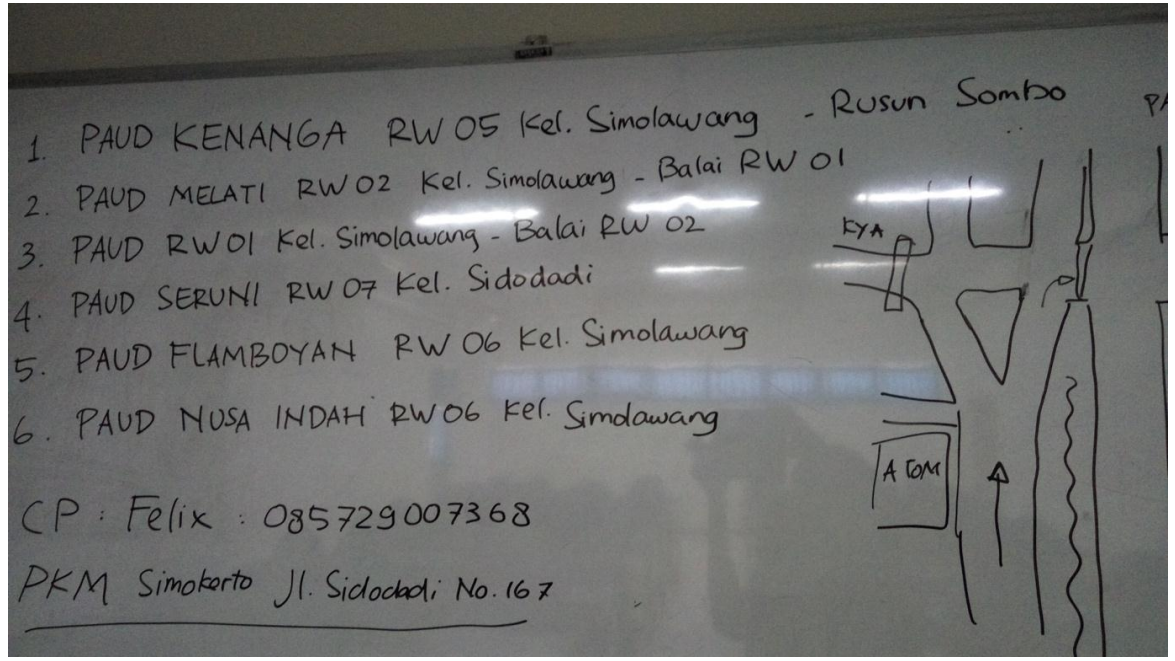

Fig. 4. The place and the map. 


\section{The output and the result}

Interview transcriptions were analyzed through a process of open coding, using the constant comparative method [9]. Checking is to ensured trust-worthiness and authenticity of the conclusions. Reflective listening techniques employed during the interview gauged the accuracy of understanding of the participants' responses as the interview progressed. Output of activities: modules and student reflection report. And after that we will discussing the result within the grup while student teaching. Taking some actions to share what they have done.

Student Reflection mostly are: (i). Learning to more thankfull and more lucky than other people. (ii). Learning to be more humble and stronger at any condition. (iii). Realized that their life is more rich and feel warm relationship with the child. (iv). Understand that every children and every place have their unique condition, so need different approach. (v). Not every children can get a good education. Therefore I should not waste my chance to learn. (vi). Learning that life is not only to receive, but also to give.

Impact of Event: (i). Students independently looking for teaching methods for the children. And also let our students looking for the location of the target community with its own energy and effort. (ii). Students gain new insight into how to teach learners well and also gain direct experience of teaching and learning activities. The benefits for target communities: Chinese language is important in the international world, so the children can understand the fundamentals of Chinese and can also be useful for their future. The learning activities to know the characters hanzi can hone the skills of students in thinking, as well as providing memory exercises on existing case characters, as well as the origin of Hanzi interesting characters can make them more open minds. (iii). Students were challenges in interaction with community, and this is helped them to improving their communication skills and gave them more confident.

A primary goal of higher education is to create responsible, moral, and productive citizens. Service-learning programs provide the opportunity for students to explore their understanding of citizenship and responsibility to society. There are many definitions of citizenship, however most of these definitions do not address how to be a citizen in a multicultural or pluralistic society [10]. In the future, we will continue to improve the process of this service-learning and build the association of professional courses and cases. Make the students game to let them more understanding about the origin and development of Simplified Chinese Letter. Some of the documentation of this program's result can be seen on the pictures below (Figure 5 to Figure 20).

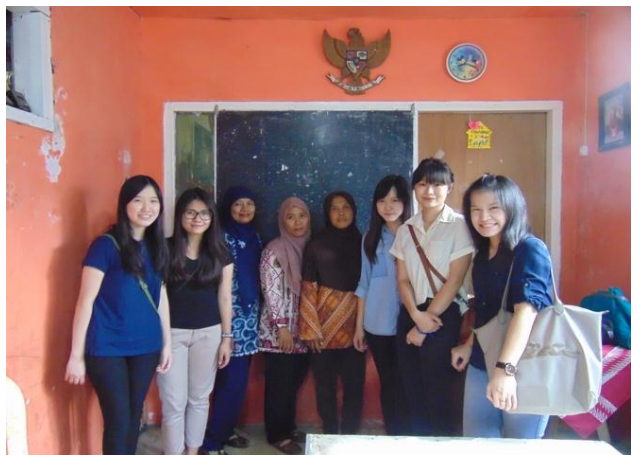

Fig. 5. Student and the group leader.

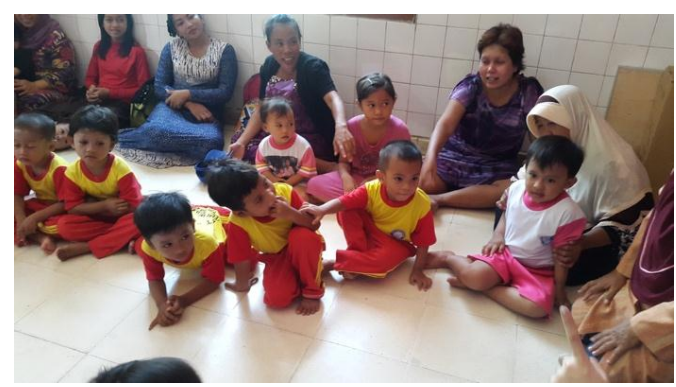

Fig. 7. Our student and the children.

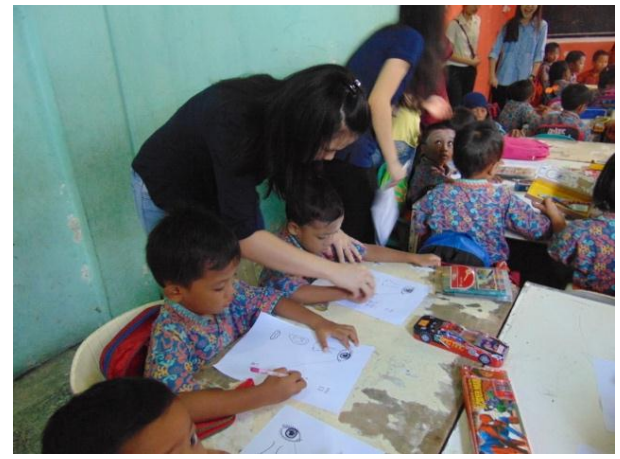

Fig. 6. Our student and the children.

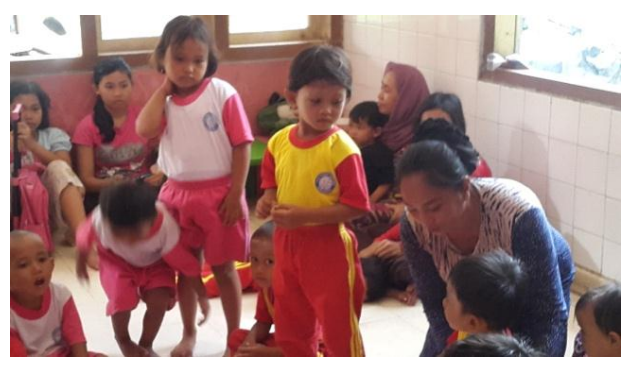

Fig. 8. Our student and the childern. 


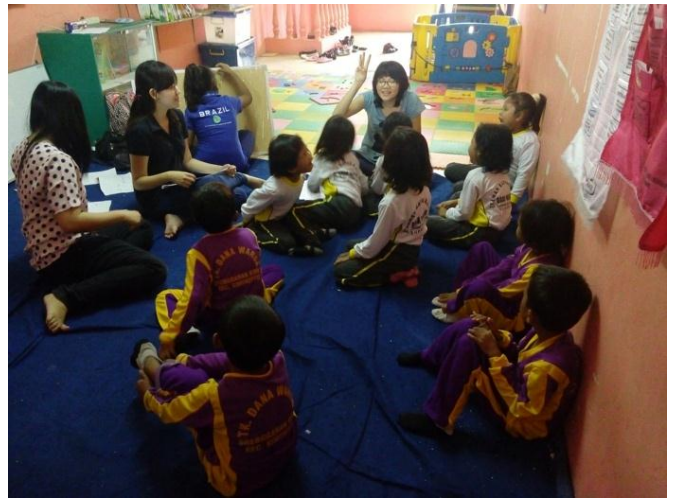

Fig. 9. Our student and the childern.

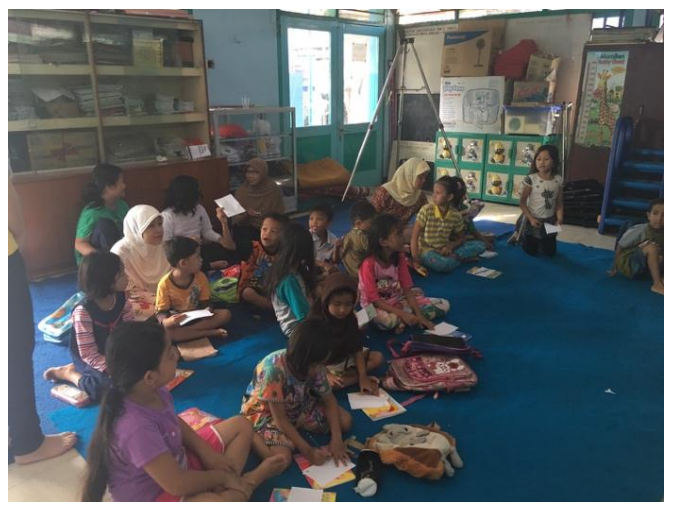

Fig. 11. Our student and the children.

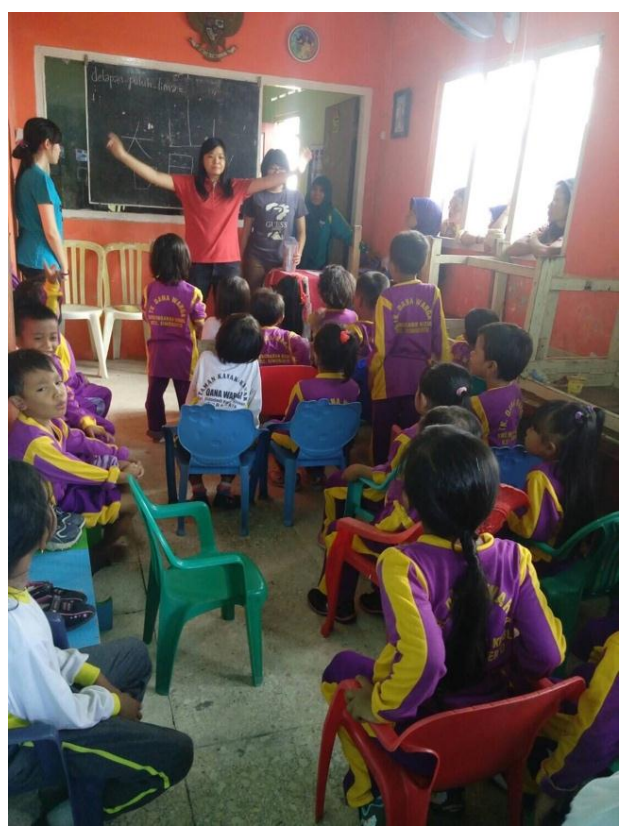

Fig. 13. Our student and the children.

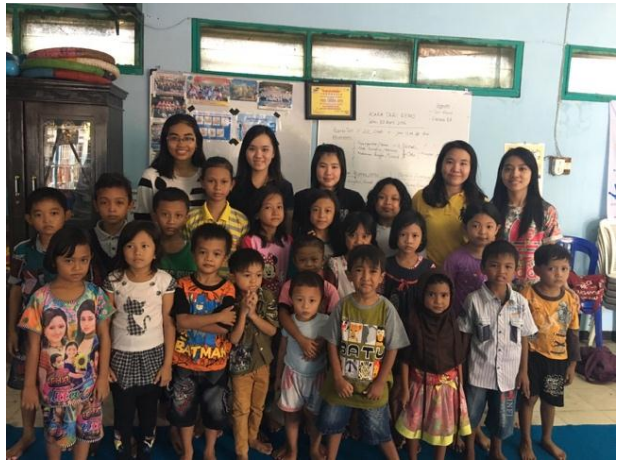

Fig. 10. Our student and the children.

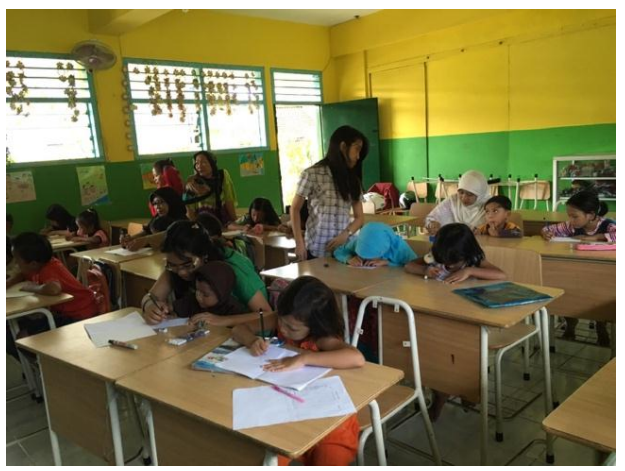

Fig. 12. Our student and the children

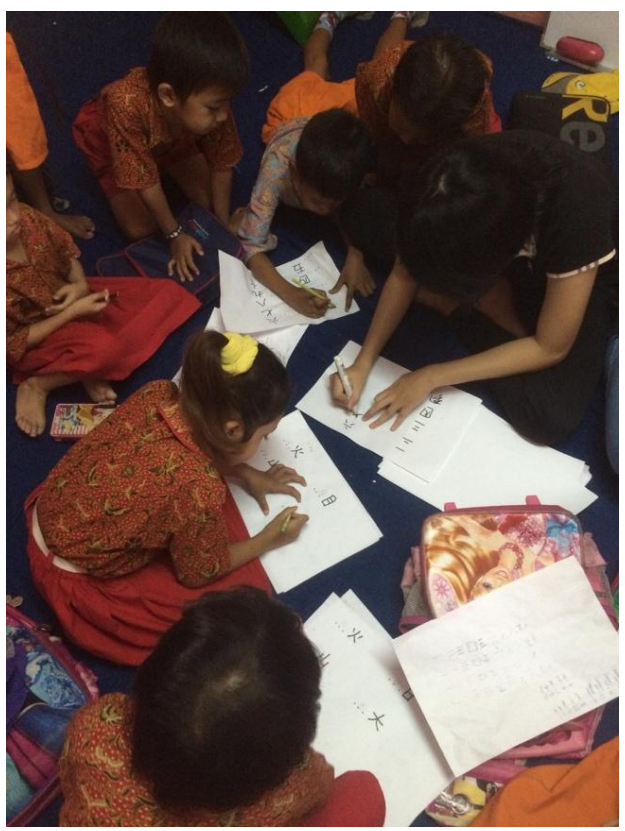

Fig. 14. Our student and the children. 


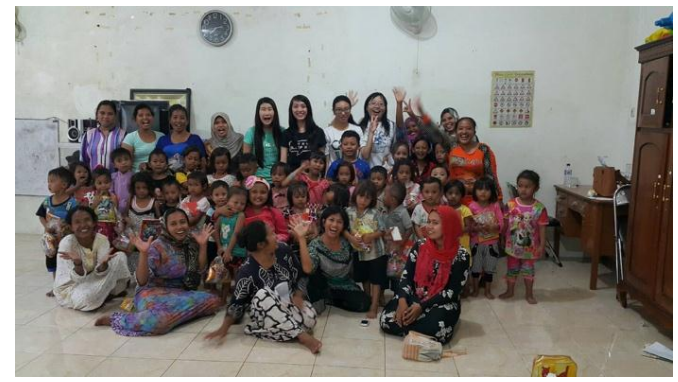

Fig. 15. Our student and the children.

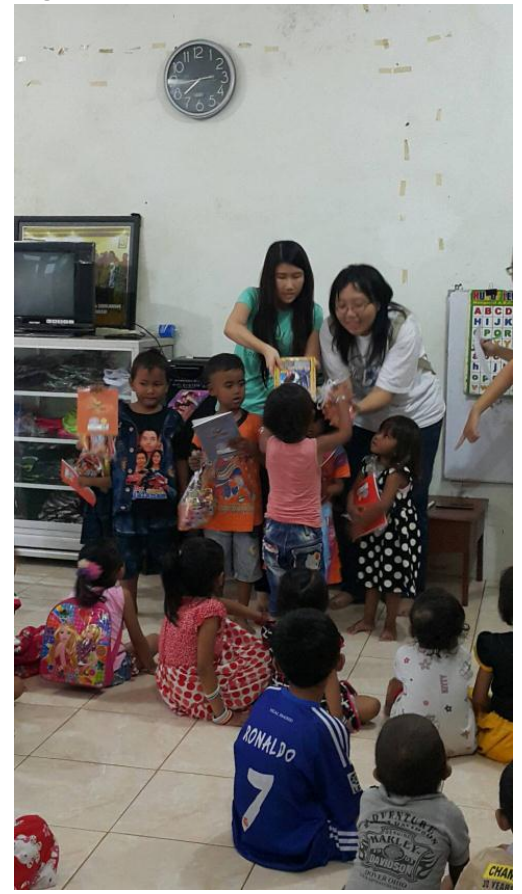

Fig. 17. Our student and the children.

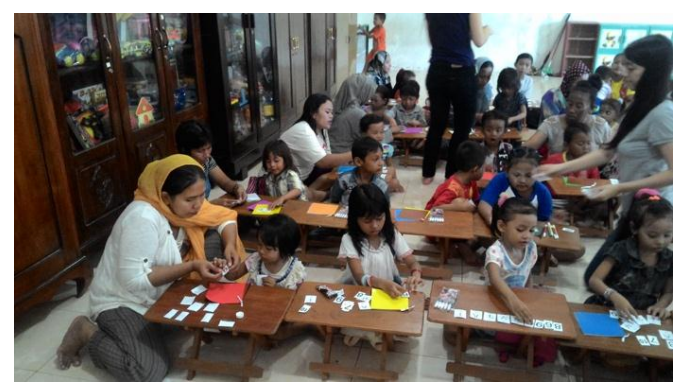

Fig.19. Our student and the children.

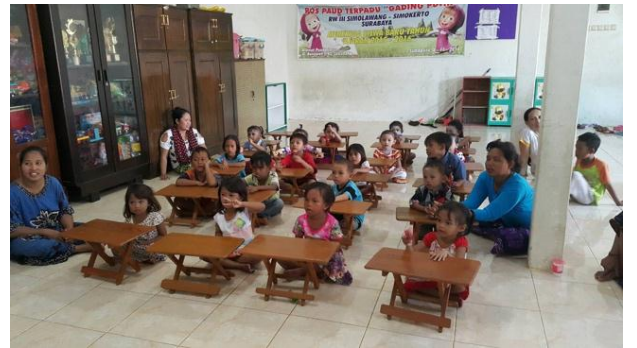

Fig. 16. Our student and the children.

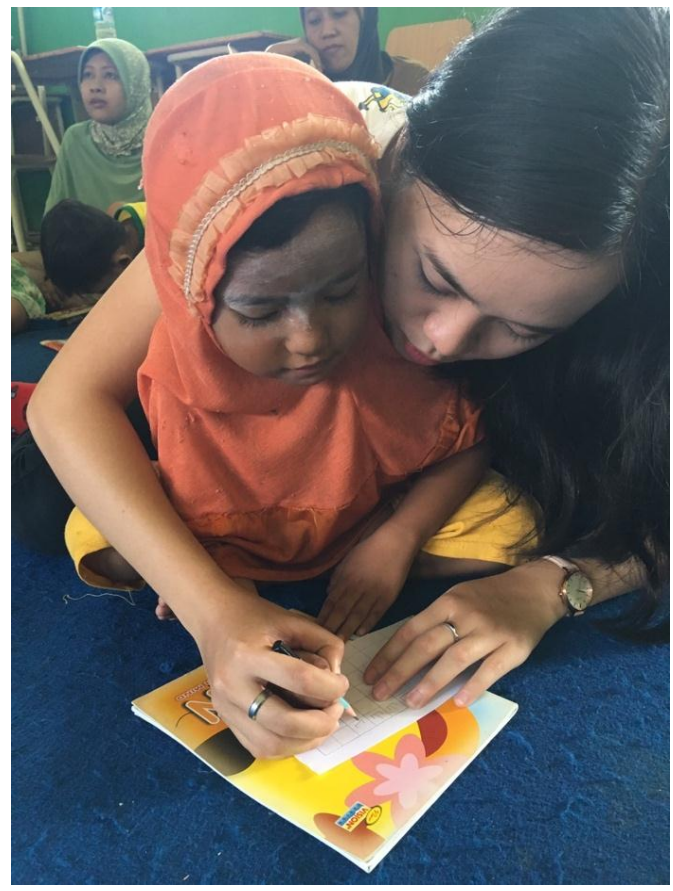

Fig. 18. Our student and the children.

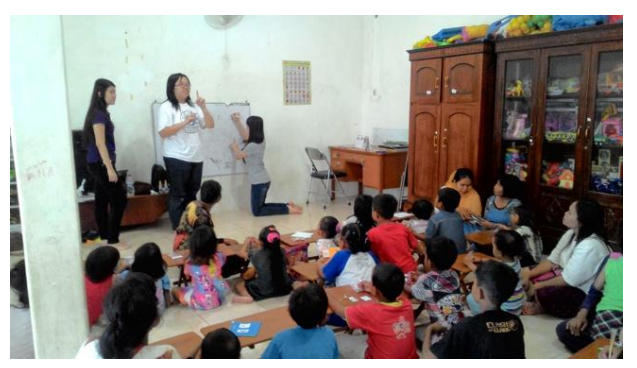

Fig. 20. Our student and the children.

\section{Conclusion}

With service-learning program on teaching Chinese characters for toddler in Surabaya, let them more understand about Chinese language and the culture behind, and create a better relationship for the next generation in Indonesia. After the progress, the children love this program and wish to know more about China and their culture. Chinese language is 
important in the international world, hence the benefit of this program are the children can understand the fundamentals of Chinese and can also be useful for their future. Beside, there are some good impact and reflection for the students who involved in this program. Service-learning programs provide the opportunity for students to explore their understanding of citizenship and responsibility to society.

\section{Reference}

1. V. Bevins. Ethnic chinese still grapple with discrimination despite generations in Indonesia. [Online] from https://www.washingtonpost.com/world/asia_pacific/ethnic-chinese-still-grapple-with-discrimination-despitegenerations-in-indonesia/2017/03/17/4abba780-0444-11e7-ad5bd22680e18d10 story.html?utm term=.9a37518b70ea (2017). [Accessed on 25 February 2017].

2. J. Forshee. Culture and Customs of Indonesia. California: Greenwood Press Westport, 2006. https://www.abcclio.com/ABC-CLIOCorporate/product.aspx?pc=B2444C.

3. World Vision Indonesia. Case study: Surabaya. [Online] from http://wvi.org/sites/default/files/SURABAYA\%20Case\%20Study2\%20web.pdf. [Accessed on 15 February $2017]$.

4. A. Kezar. About campus: Enriching the student learning experience. 7,2:14-20(2002). https://journals.sagepub.com/doi/abs/10.1177/108648220200700204?journalCode=acaa.

5. J. Eyler, D.E.J. Giles. Where's the learning in service-learning?. San Francisco, CA: Jossey-Bass (1999). https://www.amazon.com/Wheres-Learning-Service-Learning-Janet-Eyler/dp/0470907460.

6. L. Wieger. Chinese characters: Their origin, etymology, history, classification, and signification. New York: Dover Publications Inc, (2000). http://store.doverpublications.com/0486213218.html

7. Ancientscript. Chinese. [Online] from http://www.ancientscripts.com/chinese.html (n.d.). [Accessed on 27 January 2017].

8. C. Lindqvist. 漢字的故事 (China: Empire of Living Symbols). Taiwan: 貓頭鷹 (Owl Publishing House) (2006). https://www.books.com.tw/products/F011408778.

9. A. Strauss, J. Corbin. Basics of qualitative research: Grounded theory procedures and techniques. Newbury Park, CA: Sage (1990). https://www.amazon.com/Basics-Qualitative-Research-ProceduresTechniques/dp/0803932510.

10. S. Hurtado. The Review of Higher Education. 30,2:185-196(2007). https://eric.ed.gov/?id=EJ754268. 